\title{
Editorial
}

\section{Stories of Beginning Professors}

\author{
Joe Norris and Andrew Kemp \\ Guest Editors
}

"People are eager for stories. Not dissertations. Not lectures. Not informative essays. For stories" (Haven, 2007, p. 8).

The term preparation is problematic as each day is a step into the unknown for beginning professors. Preparation presupposes we know what will happen. We may and do bring acquired knowledge and skills to address that which we are about to face. However, as we embark on new adventures there will be many unanticipated events that will challenge and stretch our existing limits. They are stepping-stones to yet other adventures in an unfolding and uncertain universe. To be fully prepared means to have had that knowledge and experience prior to the event, an impossibility, a "wibbly-wobbly, timey-wimey" (Moffatt, 2007) time paradox.

But we can do the next best thing. We can listen to the stories of those who have gone before us. While they won't be exact, they can provide us with blurred glimpses of possibilities that we may not otherwise have been aware. Through them we can pre-live possibilities, asking what we might have done and recall them when we find ourselves in similar situations.

This special issue is a collection of stories about early career faculty members. Originally framed under "Dignity of the Calling" (Kemp, in press), numerous faculty members explored how they were "called" to be academics. This set specifically examines the lived-worlds of beginning professors describing a landscape of unknowns and the challenges they faced. While there are some similarities in content, especially the feeling of being unprepared, their paths are quite different. There are also vast differences in the styles of reporting. The first four are individually authored with the last four coauthored. Statistics, tables, fictionalized letters, composites and conversations are used to report, convey and portray. As Richardson (1990) claims,

Whenever we write science, we are telling some kind of story, or some part of a larger narrative. Some of our stories are more complex, more densely described, and offer greater opportunities as emancipatory documents; others are more abstract, distanced from lived experience, and reinscribe existent hegemonies. Even when we think we are not telling a story, we are, at the very least, embedding our research in a metanarrative, about, for example, how science progresses or how art is accomplished (p. 13).

This special issue of Brock Education is rich and diverse in both form and content. 
It opens with Susan Adams framing her story with Pinar's (1994) concept of currere. She takes regressive, progressive, analytical, and synthetical stances providing multiple perspectives of her life-history. Through a combination of descriptions, abstractions and a table, complete with a prediction by a former professor, Adams charts her non-lineal journey to and within the academy.

Raina León begins her piece with a playful thick-description (Geertz, 1973) about a day during the first week of her appointment. Documenting the percentage of her time spent on teaching, service, scholarship and personal activities with a chart, she provides an overview of her first year. While not strictly mixed-methods (Creswell, 2014), the interplay of two diverse styles of storytelling, both epistemologically and ontologically, reveal how one can conceptualize one's lived-experiences.

Rich in theory, Kate E. O'Hara weaves the stories of her daily practices with the words of Giroux, Freire, Kincheloe and Shor. Underpinning this article is a deep desire to enable voice in her students, their students and herself as she walks the tightrope of developing her own style and what is expected by the academy. She claims, "My research is a lived experience; I cannot separate who I am, from what I do."

Scott Richardson fictionalizes his piece. He reports a series of meetings with Daniel Myers, who "may be" himself in real life. Banks and Banks (1998) claim, "The opposite of fiction isn't truth but something like objectivity or actuality. Any genre or piece of writing that claims to be objective, to represent the actual, is a writing that denies its own existence" (p. 13). There are truths in this piece that reveal some of the tensions of trying to place into practice axiological principles that were professed and accepted during graduate school.

Employing their co-created methodology (Norris, Sawyer and Lund, 2012 and Sawyer and Norris, 2013), Joe Norris and Rick Sawyer enter into a conversation about their early university employment situations. Through juxtaposition they reinform and reinscribe each other's histories examining how coming from years of classroom teaching experiences placed additional responsibilities and expectations on them. Finding balance among competing expectations, common to many articles in this issue, was a reoccurring experience.

Jerine M. Pegg, Anne E. Adams, Hilary Smith Risser, SueAnn I. Bottoms, Anne L. Kern, and Ke Wu recognized the need of "FRiENDs, (Female Researchers in Education Networking and Dialogue)" not only in their beginning years but also throughout one's academic life as one becomes a mentor to others. They advocate "informal peer mentoring" with "a group of colleagues" across institutions "that were not vested" in the relationship. The article provides not only direction but hope as people are considered the strongest resource in navigating the academy.

Laureen McIntyre and Laurie-Ann Hellsten, two tenured faculty members at the same institution, had no formal or informal mentoring experiences in their early years. They worked independently and learned through trial and error. One strength of their piece is, at times, they make their voices distinct with readers witnessing different experiences of the phenomenon. Rather than just looking for commonalities, they also articulate differences, making the article robust. Like Pegg et al and Norris and Sawyer, they emphasis the importance of collaborative relationships.

Heather McLeod and Cecile Badenhorst recount a project involving a special edition of The Morning Watch: Educational and Social Analysis, a non-peer-reviewed 
journal published at Memorial University's Faculty of Education, in which academic research and discussion papers by faculty and students was paired with a collaborative writing process to help create a community of researchers. The collaborative writing process involved collegial discussions around proposed submissions, a workshop on narrative writing, and a review process that was developmental rather than critical. They report in-depth interviews with four submitters and advocate nurturing environments that enable beginning academics to engage in research as a process of becoming.

The above stories illustrate but a few of the many challenges that beginning faculty face and the formal and informal infrastructures of support that seem to be seldom discussed during the rush to finish one's degree. It is only after one finds oneself in the new role of faculty member does a tidal wave of new expectations wash in to replace the demand of the doctorate. This special issue, through stories, has the potential to bridge some of this transition. By providing such stories of beginning academics' livedexperiences we hope that those entering the academy may have some more information on what to expect and possibilities for action. While little can prepare one for the emotions that one may experience, like Inukshuks, we hope that these stories bring comfort with the knowledge that others have travelled here before.

\section{References}

Banks, A., \& Banks, S. (1998). Fiction and social research: By ice or fire. Walnut Creek: AltaMira Press.

Creswell, J. (2014). A concise introduction to mixed methods research. Thousand Oaks: Sage.

Geertz, C. (1973). Thick description: Toward an interpretive theory of culture. In C. Geertz (Ed.), The Interpretation of Cultures. New York: Basic Books.

Haven, K. (2007). Story proof: The science behind the startling power of story. Westport, CT: Libraries Unlimited.

Kemp, D. (in press). Dignity of the calling: Educators share the beginnings of their journeys. Charlotte, NC: Information Age Publishing, Inc.

Moffat, S. (Writer). (2007). Dr. Who Season 3, Episode 10 Blink: BBC.

Norris, J., Sawyer, R. D., \& Lund, D. (Eds.). (2012). Duoethnography: Dialogic methods for social, health, and educational research. Walnut Creek: Left Coast Press.

Pinar, W. (1994). The method of currere (1975). In W. Pinar (Ed.), Autobiography, politics and sexuality: Essays in curriculum theory 1972-1992 (pp. 19-27). New York: Peter Lang.

Richardson, L. (1990). Writing strategies: Reaching diverse audiences. Newbury Park: Sage Publications Inc.

Sawyer, R., \& Norris, J. (2013). Understanding qualitative research: Duoethnography. New York: Oxford University Press. 